\title{
THE IMPACT OF VARIABILITY OF SELECTED GEOLOGICAL AND MINING PARAMETERS ON THE VALUE AND RISKS OF PROJECTS IN THE HARD COAL MINING INDUSTRY
}

\author{
WPLYW ZMIENNOŚCI WYBRANYCH PARAMETRÓW GEOLOGICZNYCH (ZLOŻOWYCH) \\ NA WARTOŚĆ I RYZYKO PROJEKTÓW W GÓRNICTWIE WĘGLA KAMIENNEGO
}

The paper attempts to assess the impact of variability of selected geological (deposit) parameters on the value and risks of projects in the hard coal mining industry. The study was based on simulated discounted cash flow analysis, while the results were verified for three existing bituminous coal seams.

The Monte Carlo simulation was based on nonparametric bootstrap method, while correlations between individual deposit parameters were replicated with use of an empirical copula. The calculations take into account the uncertainty towards the parameters of empirical distributions of the deposit variables. The Net Present Value (NPV) and the Internal Rate of Return (IRR) were selected as the main measures of value and risk, respectively.

The impact of volatility and correlation of deposit parameters were analyzed in two aspects, by identifying the overall effect of the correlated variability of the parameters and the indywidual impact of the correlation on the NPV and IRR. For this purpose, a differential approach, allowing determining the value of the possible errors in calculation of these measures in numerical terms, has been used.

Based on the study it can be concluded that the mean value of the overall effect of the variability does not exceed $11.8 \%$ of NPV and 2.4 percentage points of IRR. Neglecting the correlations results in overestimating the NPV and the IRR by up to $4.4 \%$, and 0.4 percentage point respectively. It should be noted, however, that the differences in NPV and IRR values can vary significantly, while their interpretation depends on the likelihood of implementation.

Generalizing the obtained results, based on the average values, the maximum value of the risk premium in the given calculation conditions of the „X“ deposit, and the correspondingly large datasets (greater than 2500), should not be higher than 2.4 percentage points. The impact of the analyzed geological parameters on the NPV and IRR depends primarily on their co-existence, which can be measured by the strength of correlation. In the analyzed case, the correlations result in limiting the range of variation of the geological parameters and economics results (the empirical copula reduces the NPV and IRR in probabilistic approach). However, this is due to the adjustment of the calculation under conditions similar to those prevailing in the deposit.

Keywords: Bituminous coal deposits, geological parameters, volatility, value, risk

\footnotetext{
* THE MINERAL AND ENERGY ECONOMY RESEARCH INSTITUTE OF THE POLISH ACADEMY OF SCIENCES, 7 WYBICKIEGO STR., 31-261 KRAKOW, POLAND

\# Corresponding author: kopacz@meeri.pl
} 
W publikacji podjęto próbę oceny wpływu zmienności wybranych parametrów geologicznych (złożowych) na wartość i ryzyko projektów w górnictwie węgla kamiennego. Badania przeprowadzono w ujęciu symulacyjnym $\mathrm{z}$ wykorzystaniem analizy zdyskontowanych przepływów pieniężnych oraz zweryfikowano na przykładzie trzech rzeczywistych pokładów węgla kamiennego.

W symulacji Monte Carlo bazowano na technice bootstrapu nieparametrycznego, a zależności korelacyjne poszczególnych parametrów złożowych przestawiono przy pomocy kopuły empirycznej. W obliczeniach uwzględniono również niepewność wobec parametrów charakterystycznych rozkładów empirycznych zmiennych złożowych. Za wiodący miernik wartości wybrano wartość zaktualizowaną netto (NPV), natomiast ryzyka - wewnętrzną stopę zwrotu (IRR).

Pomiar wpływu zmienności i korelacji parametrów złożowych analizowano w dwóch aspektach, identyfikując najpierw efekt całkowity skorelowanej zmienności parametrów złożowych, a następnie efekt wpływu korelacji na NPV i IRR. W tym celu zastosowano podejście różnicowe, a w rezultacie tego postępowania, w kategoriach liczbowych, określono wartość możliwych błędów kalkulacji tych mierników.

Na podstawie przeprowadzonych badań można stwierdzić, że całkowity efekt zmienności mierzony wartością średnią nie przekracza 11,8\% w przypadku NPV i 2.4 punktu procentowego w odniesieniu do IRR. Nie uwzględnienie korelacji powoduje zawyżanie NPV o maksymalnie o 4,4\%, natomiast IRR średnio o 0,4 pkt. proc. Należy jednak podkreślić, że różnice wartości NPV i IRR mogą wahać się w znacząco większych zakresach, a ich interpretacja ma sens jedynie w odniesieniu do prawdopodobieństwa realizacji.

Uogólniając otrzymane rezultaty, bazując na średnich, maksymalna wartość premii za ryzyko z tytułu zmienności analizowanych parametrów złożowych w warunkach trzech ocenianych pokładów złoża „X”, przy odpowiednio dużych zbiorach danych (powyżej 2500), nie powinna być wyższa niż 2,4 pkt. proc. O wpływie analizowanych parametrów geologicznych na wartość NPV i IRR przesądza przede wszystkim ich współwystępowanie, które może być mierzone siłą związków korelacyjnych. Korelacje powodują ograniczenie zakresów zmienności tych parametrów, a kopuła empiryczna wpływa na obniżenie NPV i IRR w ujęciu probabilistycznym. Jest to jednak skutek urealnienia kalkulacji w warunkach bardzo zbliżonych do naturalnych w złożu.

Słowa kluczowe: Złoża węgla kamiennego, parametry geologiczne, zmienność, wartość, ryzyko

\section{Introduction}

The exploitation of bituminous coal is accompanied by risk. The sources of uncertainty and risk factors can be both external and internal, associated with the individual deposit and its exploitation. According to Gochta et al. (1988), Le Bela (1993), Davis (1998), Torries (1998), Simonsen and Perry (1999), Hammond (2000), Smith (2000), Roberts (2000), and - in the case of Polish literature - Wanielista et al. (2002), and Uberman and Uberman (2008) the most important components of risk and obstacles during mining projects include: exploitation and geological factors related to the deposit structure, concessions and licenses, and marketing and financial factors associated with raising capital. The correct assessment of the amount of reserves, completion date, the level of production, costs, capital expenditures, price volatility, demand for the produced goods, currency exchange rates, or inflation are also of great importance. Lattanzi et al. (2000) and Smith (1994) pointed out that mineralization of the raw material in the deposit and the dilution resulting from the occurrence of coal partings and gangue during exploitation can be viewed as another important source of value and risk. Among the key risk areas, Saługa (2009) lists economic, financial, and technological aspects (related to environmental protection), as well as the state of the economy, political and legal situation, infrastructure, geographic location, climatic conditions, and social relations. Sobczyk (2009), Khanzode et al. (2011), and Zhu (2011) add broadly understood natural hazards, sedimentatory disturbances, depth and thickness of a seam with coal partings, dip angle, the workability of coal, and roof and floor conditions. However, according to Smith (2000), the accuracy of estimation of reserves is one of the most 
important components of the value and risk assessment of mining projects. Depending on the degree of deposit exploration, the following errors in estimating the average deposit parameters are assumed (in the A + B category: $\pm 20 \%, \mathrm{C} 1: \pm 30 \%, \mathrm{C} 2$ and $\mathrm{D}: \pm 40 \%$ ) (Nieć, 1990). The need to pay attention to the accuracy of evaluation of deposit parameters, taking into account the future land-use planning and high-performance exploitation, has already been underlined by Kozubski (1962). The importance of thickness and errors of its measurements have also been emphasized by Górecka (1981).

However, a review of the professional literature suggests a lack of analyzes focusing on the evaluation of individual and correlated impact of individual deposit parameters on the value and risks of mining projects. The analysis is based on the adopted analysis method, assessment criteria, and assumptions. The individual aspects are independently analyzed and the scope of analysis is limited to particular cases. The fact that the observed variability of deposit parameters contains an element of natural variation and measurement errors, even though the separation of these two components is ultimately a matter of subjective interpretation, is often overlooked (Wasilewska \& Mucha, 2006; Mucha et al., 2007; Dimitrakopoulos et al., 2007). There are a lot of differences and conflicting information regarding assessing the impact of deposit parameters on specific categories of value and risk, while the risks associated with geological parameters is often chosen arbitrarily. The mentioned parameters are estimated from a few percent up to several times higher (Smith, 2000; Mucha et al., 2008). Meanwhile, the impact of geological parameters is of great importance, which has been confirmed by Li et al. (2008) and Berry and McCarthy (Berry \& McCarthy, 2006). It is also worth noting that the variability of geological parameters of bituminous coal deposits provides an opportunity to obtain more satisfactory results than expected (Pera, 2010).

Meanwhile, the impact of geological (deposit) parameters is only partially negative. The negative impact on the deposit is observed when the calorific value and the thickness of the deposit (without coal partings) is below the average, while in the case of ash and sulphur content, and intergrowth thickness - when the values are above the average. The impact of density is debatable. Generally, higher density has positive impact on the amount of resources, while strong correlation with the ash content can provide information about the increased amount of coal processing waste.

Theoretically, the uncertainty associated with the assessment of deposit parameters resulting from a multiplicity of data sets is also of great importance, even though only the influx of negative information can have the negative impact on the valuation of coal reserves (Vose, 2008).

The paper attempts to assess the impact of variability of selected geological (deposit) parameters on the value and risks of projects in the hard coal mining industry This risk was included in the discount rate, which is the most common practice (Graham \& Harvey, 2001) and was measured by the volatility of the Net Present Value (NPV) and Internal Rate of Return (IRR). The study used the Monte Carlo method, allowing dynamic sampling of distributions with specified variables. The scope of the analysis was limited to three seams of the " $\mathrm{X}$ " deposit, while detailed results of calculations were presented only for the $\mathrm{C}-1$ deposit. This is the most prospective and abundant deposit. The scale of the error resulting from the omission of the aspect of the coexistence of deposit parameters was measured by the correlation method. Finally, the parameters with the strongest impact on the NPV and IRR were identified. 


\section{Discounted cash flow analysis and the assessment model}

\subsection{Identification of free cash flow and the measures of value and risk}

To assess the risks associated with the variability of deposit parameters, a discounted cash flow analysis has been used. The construction of the Free Cash Flow was based on estimating the Free Cash Flow to Firm (FCFF) without strict adherence to the regime of the adequacy of the free cash flow and the discount rate, which resulted from the essence of the model. The determination of free cash flows was preceded by the calculation of:

- Exploitable resources of the mine: $Z_{w} ;[\mathrm{Mg}]$

- Coal production: $C p: f\left(W n, \beta_{t}\right) ;[\mathrm{Mg}]$

- Sales revenue: $R: f\left[C p, P\left(Q^{r}, S^{r}, A^{r}\right)\right] ;[\mathrm{PLN}]$,

- Cash operating costs: $K g: f[(C p, F, J K s, J K z, C Y c)] ;[\mathrm{PLN}]$,

- Profits: EBITDA, EBIT; [PLN],

- Income tax: $P d ;$ PLN],

- NOPAT profit (loss): NOPAT; [PLN],

- NOPAT adjustments related to:

- Amortization of fixed assets: $A$; [PLN],

- Capital expenditures: $N i$; [PLN],

- Net working capital: $d K O N$; [PLN],

- Residual value: $R w$; [PLN],

Where: $W n$ is a net coal output (assumed as a function of the amount of reserves, for which the base production costs were calculated, $k_{b}$ [PLN/Mg]), $\beta_{t}$ - potential losses of coal in coal processing, [\%], $P$ is the price of coal, [PLN/Mg]. $Q^{r}[\mathrm{GJ} / \mathrm{Mg}], S^{r}[\%], A^{r}[\%]$ mark qualitative parameters of coal in the deposit, $J K s, J K z$ - unit cash production cost (fixed and variable parts), [PLN/Mg] respectively, $C Y c$ - coal yield (percentage coal output related to run-of-mine), [\%], $F$ - denotes mining height, [m].

Mathematical form of the calculated profits and cash flows is presented by the following formulas (1-4):

$$
\begin{gathered}
E B I T D A=R-K_{g} \\
E B I T=E B I T D A-A \\
N O P A T=E B I T-P d \\
F C F=N O P A T+A-N i+d K O N+R_{w}
\end{gathered}
$$

where: EBITDA; [PLN] is a measure of cash profit (the earnings minus production costs, e.g. excluding amortization and depreciation, which are calculated separately for capital expenditures), $E B I T ;$ [PLN] - a measure of a firm's profit before interest and tax expenses, NOPAT; [PLN] is net operating profit after taxes, and $F C F$; [PLN] denotes free cash flow. The residual value corresponded to the balance sheet total of the unamortized portion of fixed assets (expenditures) and the net working capital in the last year of the analysis. Then the adopted free cash flows were updated to the current values in accordance with the requirements of the NPV method and the adopted discount rate. 
壳

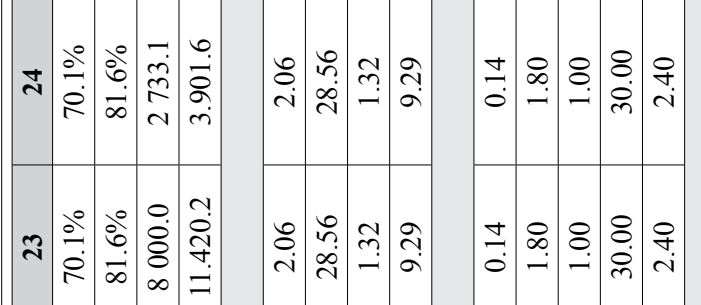

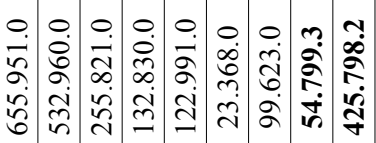

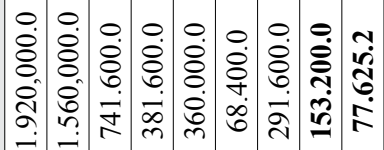

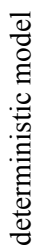

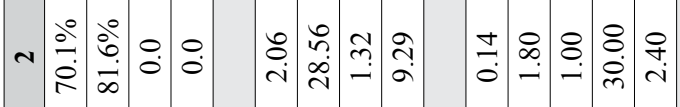

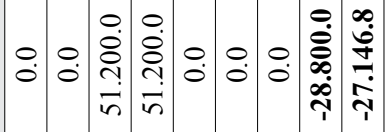

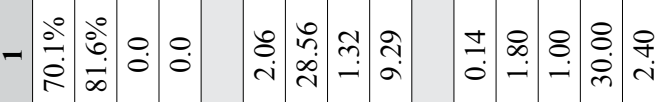

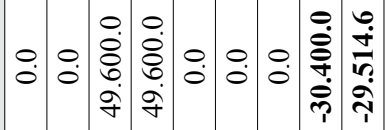

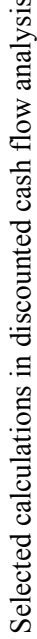

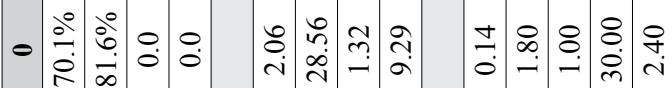

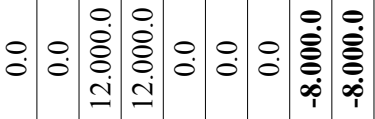

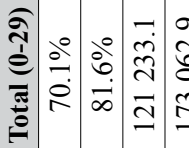

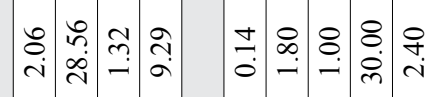

마 范

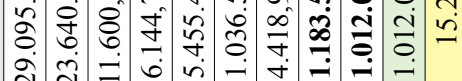

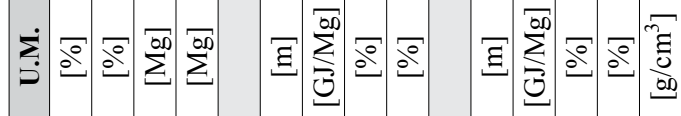

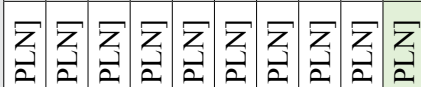
닐

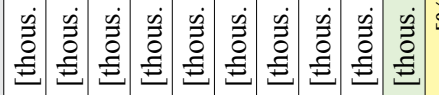

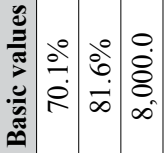

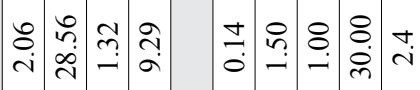

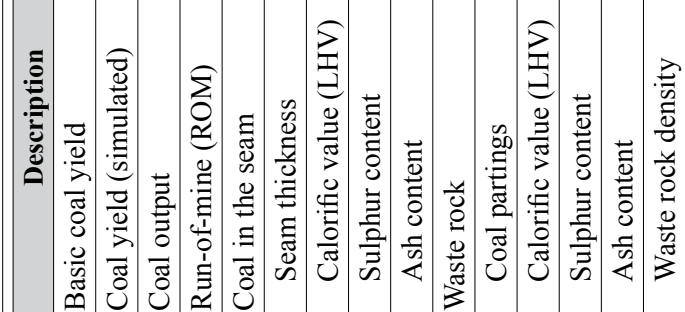

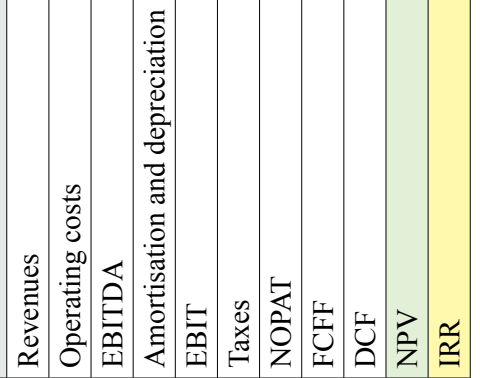


Table 1 presents selected parts of spreadsheets containing fixed values of the average thickness and quality parameters of the $\mathrm{C}-1$ deposit and other economic and financial variables. The base $N P V$ for this seam was calculated at about 1.01 billion PLN. The internal rate of return (IRR) amounted to $15.2 \%$

As already mentioned, the assessment of the impact of deposit parameters used the NPV and $I R R$ methods. The NPV (net present value) is the sum of the current (updated) annual cash flows minus initial investment expenditures. The $N P V$ reflects the value of the project at a given discount rate and number of assumptions regarding cash flow. The $N P V$ is therefore a measure of the value of the investment.

The internal rate of return can be defined as the discount rate at which the $N P V$ is equal to zero. Thus, $I R R$ is the rate that equalizes the size of the initial investment with the actual value of future cash flows. The higher the IRR, the more ",profitable“ is a project in terms of return on invested capital. The classic formula interconnecting the net present value and internal rate of return shown is presented by the following equation:

$$
N P V=0=\left[\sum_{1}^{n} \frac{C F_{t}}{(1+I R R)^{t}}\right]-I_{0}
$$

Where:

$C F_{t}$ - Cash flow in the t year [PLN],

$I_{0}$ - Initial investment expenditures [PLN],

$n$ - The total number of years required for the project implementation, the variable in the simulation.

\subsection{The quantification of the impact of the quality parameters of coal on its price and sales revenue}

To estimate the correlated impact on the price of all the quality parameters of coal, the original concept of empirical copula, introduced to the formula for determining the price of coal, has been used. The mathematical form of this formula is as follows:

$$
P_{i}=P_{b} \cdot \frac{Q_{i}}{Q_{b}^{r}}-C_{e} \cdot \frac{S_{i}}{S_{b}^{r}}-C_{e} \cdot \frac{A_{i}}{A_{b}^{r}}
$$

Where:

$C_{e}-$ The empirical copula; [\#],

$P_{i}$ - The calculated sale price; $[\mathrm{PLN} / \mathrm{Mg}]$,

$P_{b}$ - The price of coal characterized with average quality parameters; [PLN/Mg],

$Q_{i}$ - The calorific value $(L H V) ;[\mathrm{GJ} / \mathrm{Mg}]$,

$Q_{b}^{r}$ - The average calorific value $(L H V)$ of coal in a given seam; [GJ/Mg],

$S_{i}$ - Sulphur content; [\%],

$S_{b}^{r}$ - The average total sulphur content in a given coal seam; [\%],

$A_{i}$ - The ash content; [\%],

$A_{b}^{r}-\mathrm{T}$ he average ash content in a given coal seam; [\%]. 
Formula no. 6 gives similar estimates of coal prices as the pricing formula presented by Grudziński et al. (Grudziński et al., 2009). Revenues from coal sales were in turn calculated as the product of price and the production of coal, which (simplified) corresponded to the net coal output. Definition and scope of implementation of the empirical copula is presented in chapter 3.1.

\subsection{Parameterization of the impact of a seam thickness, density, and partings on the cost of coal production.}

The basis for measuring the impact of the thickness, density, and partings of a coal seam on costs, free cash flow, and selected measures of value was the assumption that production costs significantly depend on the structure of the mined reservoir rocks. A more detailed discussion of these aspects was presented by Kopacz (2015a, 2015b). The structure of excavated material, taking into account the processing of coal (to simplify, only coal concentrate and coal waste are analyzed) affects the yield of coal defined by the formula No.4.

In order to illustrate the relationship between the coal production costs and the structure of the output, the mining height (adapted to the conditions prevailing at the deposit) was determined and the sources of pollution in the " $X$ " mine were identified. It was assumed to describe the mining height $F$ with the following formula (7):

$$
F=h_{w}+h_{p}+h_{p s}+h_{o s}
$$

Where: $h_{w}, h_{p}, h_{p s}, h_{o s}$ - denote coal seam thickness (without partings), coal partings, dinting and floor cutting, roof falls and ripping, respectively.

The yield of coal output, [\%] is in turn defined by the following formula (8):

$$
C Y_{c}=(1-\beta) \cdot \frac{\rho_{w}^{r} \cdot h_{w} \cdot Q_{w}^{r}+\rho_{p}^{r} \cdot h_{p} \cdot Q_{p}^{r}+\rho_{s}^{r} \cdot h_{s} \cdot Q_{s}^{r}+\rho_{r}^{r} \cdot h_{r} \cdot Q_{r}^{r}}{\rho_{w}^{r} \cdot F \cdot Q_{w}^{r}}
$$

Where: $C Y c$ - the yield of coal output, $\rho_{w}^{r}, \rho_{p}^{r}, \rho_{s}^{r}, \rho_{r}^{r} ; h_{w}, h_{p}, h_{s}, h_{r} ; Q_{w}^{r}, Q_{p}^{r}, Q_{s}^{r}, Q_{r}^{r}$ are the density, thickness and the coal LHV in the deposit, coal partings, gangue, floor dinting, roof falls and ripping, respectively. $F$ - mining height and $\beta$ is coal loss during the processing of coal. In all models, it is assumed that $\beta=0.01$ ( $1 \%$, the loss of the finest fraction of coal).

Estimation of the yield of coal output $(C Y c)$ was followed by calculation of the individual and total production costs, broken down into fixed and variable costs, using a formula developed by (Kopacz, 2015b). The design of these formulas is based on the observed variability in operating costs of longwall faces characterized by a highly variable seam thickness and different exploitation methods. The formula for estimating fixed costs (9) was as follows:

$$
J K s=J K s_{b} \cdot \frac{C Y c_{(b)}}{\left(C Y c_{(i)} \cdot W E K s\right)}
$$

Estimation of the variable costs uses the following formula (10):

$$
J K z=J K z_{(b)} \cdot\left[\left(C Y c_{(b)}-C Y c_{(i)}\right) \cdot W E K z+1\right]
$$


Where:

$J K s$ - The unit fixed costs (expected), PLN/Mg;

$J K s_{b}$ — The unit fixed costs (baseline), PLN /Mg;

$J K z$ - The unit variable costs (expected), PLN /Mg;

$J K z_{(b)}$ - The unit variable costs (baseline), PLN /Mg;

$C{ } c_{(b)}$ - The coal production (coal yield) (baseline), \%;

$C Y_{(i)}$ - The coal production (coal yield) (simulated), \%;

$W E K s$ - The coefficient of elasticity of fixed costs compared to the coal production $C Y c$,

$W E K z$ - The coefficient of elasticity of variable costs compared to the coal production $C Y c$.

The production cost was the sum of the total fixed and variable costs estimated at a given yield of coal sold.

\section{Measuring the impact of deposit parameters on the value and risks related to the exploitation of the C-1 seam in the Monte Carlo simulation}

The assessment of the impact of deposit parameters on the value and risks related to the exploitation of coal in the C-1 seam was carried out on the basis of the simulation model based on the structure of the discounted cash flow analysis. The variables were divided into explanatory (input parameters) and projected (output parameters). Explanatory variables covered by the empirical distributions were in particular:

- The coal quality parameters (calorific value, sulphur and ash content)

- The thickness of the C-1 deposit (without coal partings),

- The coal partings,

- The density of coal.

The estimated variables included:

- NPV,

- IRR.

In the end result, this information formed the basis for the probabilistic and quantitative assessment of the projected variables. Graphical form of the analysis is shown in Figure 1.

The identification and analysis of the overall impact of the variability of deposit parameters was performed in a two-step procedure:

1. The quantification of the correlated impact of the variability and uncertainty of all deposit parameters was followed by

2. Identification and isolation of the ,pure“ impact of the correlation taken into account in the simulation using the empirical copula.

The first of the analyzed impacts shows the economic effect of not taking into account the natural variability and the correlation of deposit parameters, while the second - using a differential approach - shows the numerical result of excluding the correlation from the valuation model.

To achieve these objectives, two parallel models - deterministic and simulation model of identical structure of cash flows, were constructed. The simulation model also included a pricing 


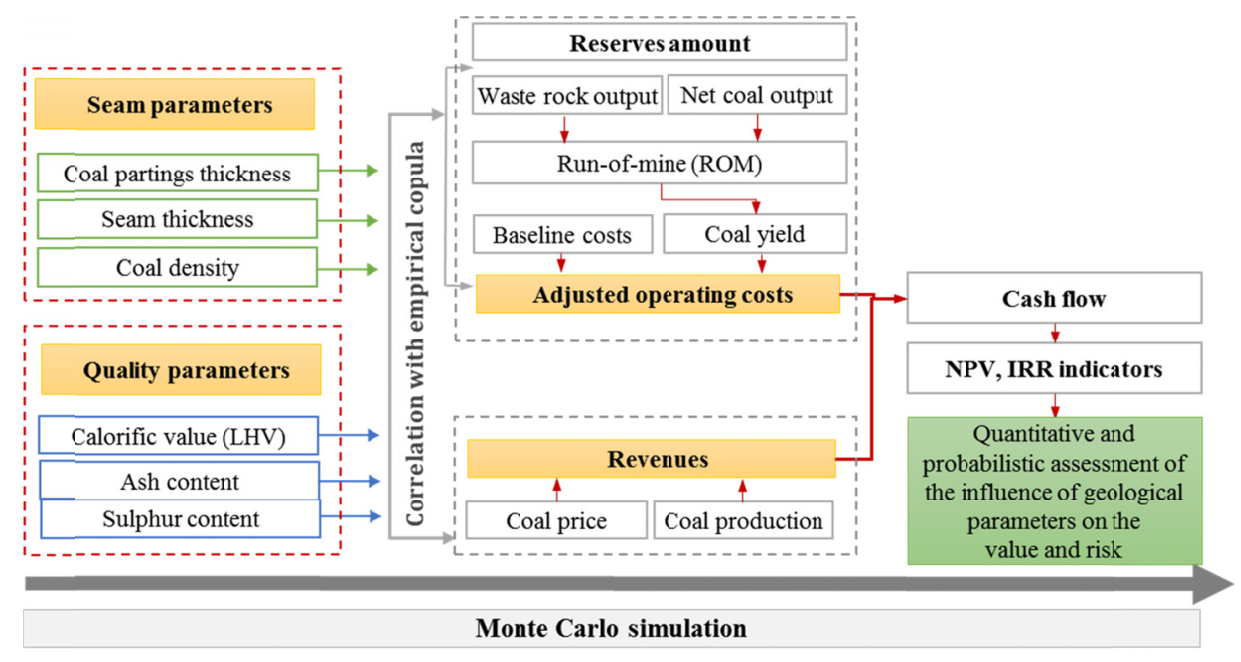

Fig. 1. The concept of the analysis. Source: own study

formula with the empirical copula (equation no. 6), formulas describing the operational costs (formula No. 9 and 10), and was calculated $100 \mathrm{k}$. times.

In the first phase, the distribution of differences $\left\{N P V_{d e t}-N P V_{\left(c^{+}\right)}\right\}$and $\left\{I R R_{d e t}-I R R_{\left(c^{+}\right)}\right\}$ were generated. In order to separate the correlation from the total variability of $N P V$ and $I R R$, distribution of differences $\left\{N P V_{i\left(C^{-}\right)}-N P V_{i\left(C^{+}\right)}\right\}$and $\left\{I R R_{i\left(C^{-}\right)}-I R R_{i\left(C^{+}\right)}\right\}$were generated, where $\left(c^{-}\right)$denoted $N P V$ or IRR (no correlation) and $\left(c^{+}\right)$denoted NPV (IRR) generated on the basis on the correlation. $N P V_{d e t}, I R R_{\text {det }}$ represent the values of indicators in the deterministic model.

\subsection{The technique of sampling distributions and correlating variables}

The work has applied nonparametric bootstrap technique and copulas - used as functions correlating the deposit parameters. The bootstrap technique used directly empirical observations and the resulting distributions, allowing constructing the distribution statistics in the general population, instead of a specified form of the theoretical distribution (Efron, 1993). The empirical copula was correlating function. Generally, $d$-dimensional copula $(C)$ can be presented (based on the Sklar theorem) (Cherubini et al., 2004) as a multidimensional distribution $F$, whose boundary functions (martingales) $\left(F 1, F 2, \ldots, F_{d}\right)$ take the form of uniform distributions $U(0,1)$ on the interval $[0,1]$, which can be expressed in the form (2):

$$
F\left(x_{1}, x_{2}, \ldots, x_{d}\right)=\mathrm{C}\left(F_{1}\left(x_{1}\right), F_{2}\left(x_{2}\right), \ldots F_{d}\left(x_{d}\right)\right)
$$

The empirical copula represents the original, irregular pattern of correlation between the variables. It is generated using a bootstrap technique on the basis of the set of ranged observations, while ranks are related to a particular quantile (percentile) in an $n$-element data set (Vose, 2008). The simulation takes into account the uncertainty towards the parameters of empirical distributions of the individual deposit variables. Thus, a single empirical distribution of a given 
deposit parameter is replaced by a family of distributions drawn from the data set and distributions statistics are estimated.

The empirical distribution is in turn the first-order distribution, defined by minimum and maximum limitations in the collection of empirical data in the following form: $f(x)=($ min, max, data $)$. It is worth mentioning that the minimum and maximum for the empirical distribution are subjectively determined based on the analyst's knowledge of the variable. For a continuous variable, these values will generally be outside the observed range of the data (assign as " $n+1$ ") (Vose, 2008). The function of the density in this distribution can be described as follows:

$$
f(x)=\frac{1}{n+1} \cdot \frac{1}{x_{i+1}-x_{i}} \text { for } x_{i} \leq x \leq x_{i+1} ; \quad i \in\{0,1, \ldots, n+1\}
$$

Where: $x_{0}=\min ; x_{n+1}=\max ; P\left(x_{0}\right)=0$ i $P\left(x_{n+1}\right)=1$.

Cumulative distribution function takes the following form: $F(x)=\frac{i}{n+1}$, while the average value can be calculated with the following formula: $\frac{1}{n+1} \sum_{i=0}^{n} \frac{x_{i}+x_{i+1}}{2}$, where $n$ is the number of observations. The approximation of variance, skewness, and kurtosis for this distribution is complicated.

\section{Data sources and key assumptions in the analysis}

\subsection{Sources of geological data}

The analysis used the data from the digital geological model of the " $X$ " deposit. This model is developed and constantly updated in the Division of Mineral Resources Acquisition of the Mineral and Energy Economy Research Institute of the Polish Academy of Sciences (MEERI PAN). The geological model of the "X" deposit was developed on the basis of a total of over 530 thousand records with source data, including:

- 97 surface boreholes and 125 underground boreholes with detailed description of all lithological units,

- 337 and 5.809 records from measuring stratigraphic sections of longwalls and mine workings,

- 1.336 sets of qualitative analysis.

The C-1 seam, in addition to the type 32 and 33 coal, also contains the type 34 coal (34.1 and 34.2). Balanced resources were estimated at 169 million $\mathrm{Mg}$. The map of the $\mathrm{C}-1$ seam with location of longwalls is presented in Fig. 2.

Table 2 presents, in turn, the basic descriptive statistics of the analyzed deposit parameters in the $\mathrm{C}-1$ seam.

Table 3 presents the correlation of selected geological parameters of the $\mathrm{C}-1$ seam. The low and medium relationships are dominating. The highest negative correlation is shown by the coal LHV and ash content (-0.67), while the highest positive $(0.78)$ - by the density of coal and ash content. 


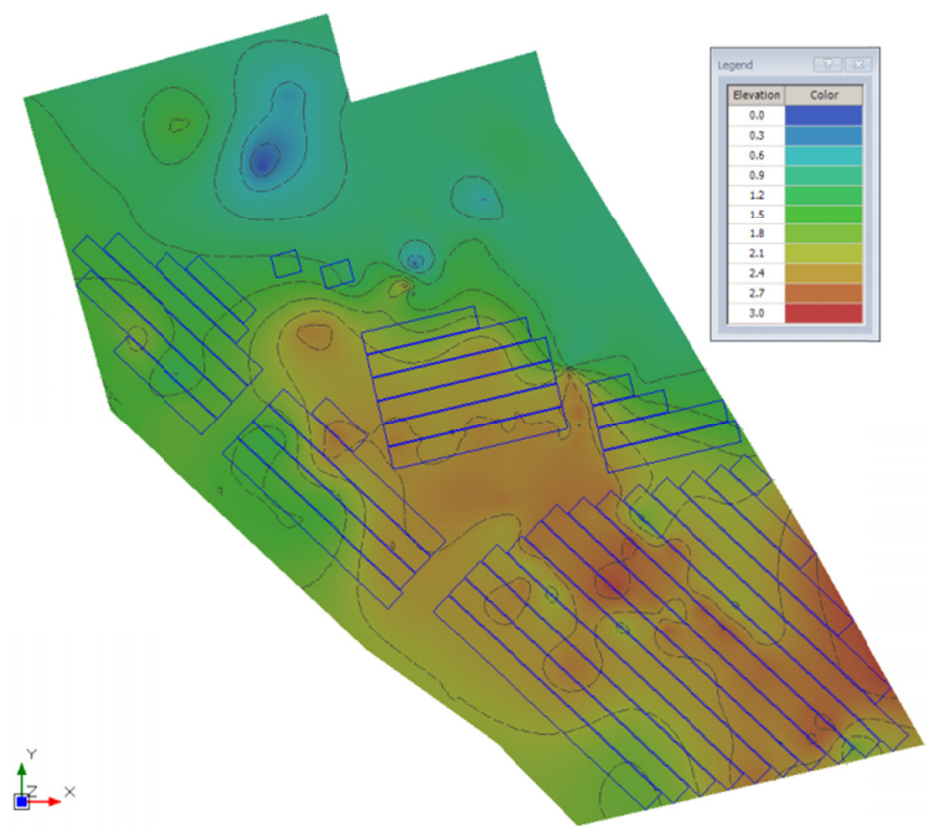

Fig. 2. Map of the C-1 seam thickness and the adopted location of the longwalls. Source: (Kopacz, 2016)

The basic descriptive statistics of the recoverable reserves of coal in the C-1 seam

\begin{tabular}{|c|c|c|c|c|c|c|}
\hline Description & $\begin{array}{c}\text { Seam } \\
\text { thickness } \\
(\mathrm{ST})\left({ }^{*}\right)[\mathrm{m}]\end{array}$ & $\begin{array}{c}\text { Calorific } \\
\text { value (LHV) } \\
\text { (Qr) [GJ/ } \\
\text { Mg] }\end{array}$ & $\begin{array}{c}\text { Sulphur } \\
\text { content (Sr) } \\
{[\%]}\end{array}$ & $\begin{array}{l}\text { Ash content } \\
\text { (Ar) }[\%]\end{array}$ & $\begin{array}{l}\text { Coal density } \\
\text { (Cd) }[\mathrm{g} / \mathrm{cm} 3]\end{array}$ & $\begin{array}{c}\text { Coal } \\
\text { partings (P) } \\
{[\mathrm{m}]}\end{array}$ \\
\hline $\begin{array}{l}\text { Number of } \\
\text { observations }\end{array}$ & 2500 & 2500 & 2500 & 2500 & 2500 & 2500 \\
\hline Mean & 2.06 & 28.56 & 1.32 & 9.29 & 1.34 & 0.14 \\
\hline Median & 2.26 & 28.59 & 1.25 & 8.67 & 1.34 & 0.11 \\
\hline Minimum & 0.08 & 23.55 & 0.16 & 2.64 & 1.27 & 0.01 \\
\hline Maximum & 3.00 & 31.97 & 2.63 & 19.79 & 1.46 & 0.79 \\
\hline Lower quartile & 1.65 & 27.75 & 0.96 & 6.86 & 1.32 & 0.06 \\
\hline Upper quartile & 2.49 & 29.37 & 1.64 & 11.16 & 1.36 & 0.18 \\
\hline Standard deviation & 0.60 & 1.29 & 0.48 & 3.26 & 0.03 & 0.11 \\
\hline Coefficient of variation & $29.0 \%$ & $4.5 \%$ & $36.1 \%$ & $35.1 \%$ & $2.6 \%$ & $80.4 \%$ \\
\hline Skewness & -1.00 & -0.15 & 0.50 & 0.85 & 0.40 & 1.95 \\
\hline Kurtosis & 0.33 & 0.21 & -0.35 & 0.44 & -0.15 & 5.24 \\
\hline $\begin{array}{l}\text { Confidence interval for } \\
\text { mean }(\mathrm{P}=0.95)\end{array}$ & $2.04-2.08$ & $28.51-28.61$ & $1.31-1.34$ & $9.16-9.42$ & $1.34-1.34$ & $0.14-0.15$ \\
\hline $\begin{array}{l}\text { Mean estimation error } \\
(\mathrm{P}=0.95)\end{array}$ & $1.14 \%$ & $0.18 \%$ & $1.41 \%$ & $1.38 \%$ & $0.10 \%$ & $3.15 \%$ \\
\hline
\end{tabular}

Description: $(*)$ - seam thickness without coal partings. Source: own study 

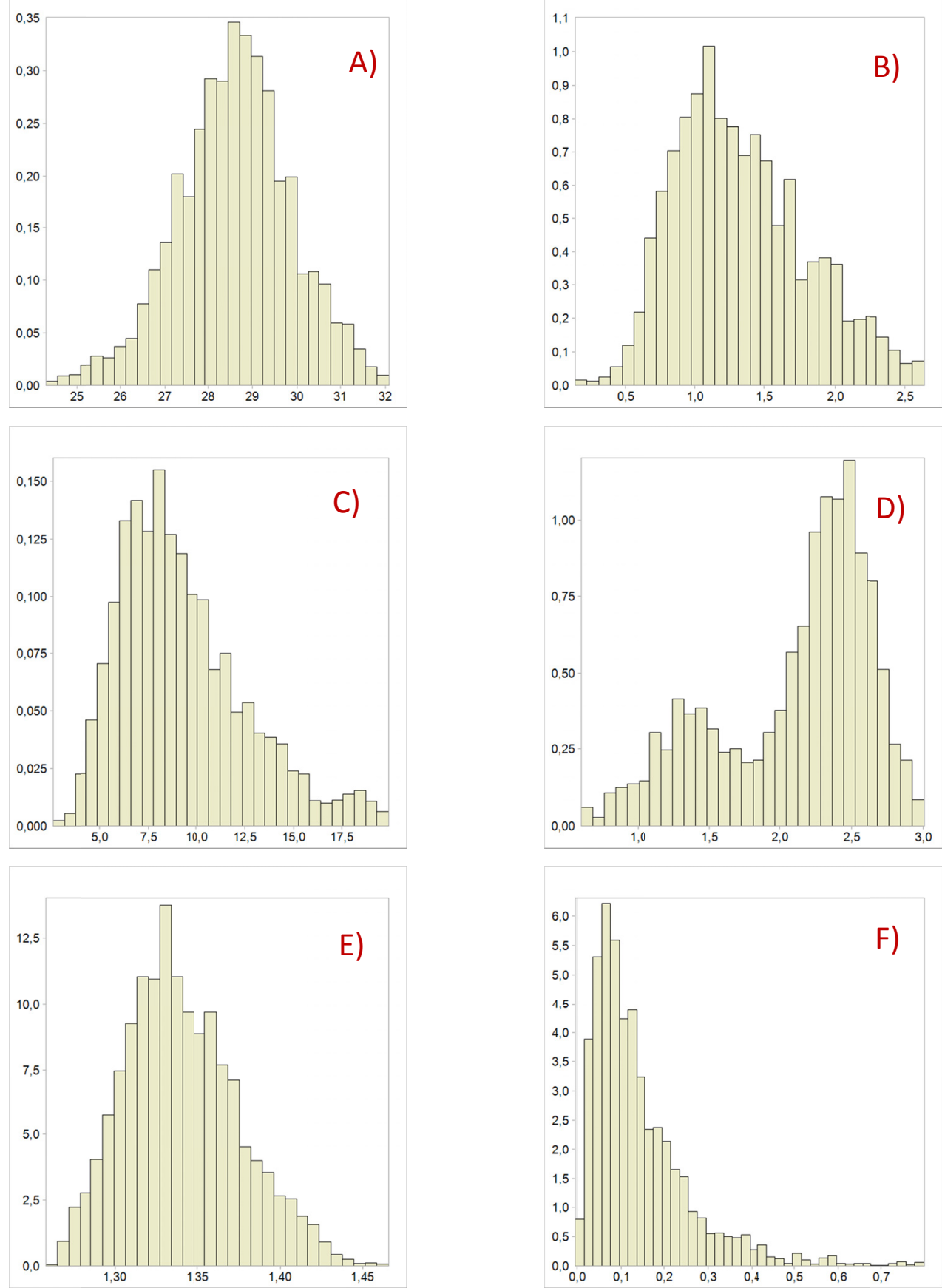

Fig. 3. Distribution of the $\mathrm{C}-1$ seam parameters: A) - the coal LHV [GJ/Mg], B) sulphur content [\%], C) ash content [\%], D) seam thickness (without coal partings) [\%], E) density of coal $\left[\mathrm{g} / \mathrm{cm}^{3}\right]$, coal partings $[\mathrm{m}]$. Source: own study 
Correlations of the analyzed geological parameters (Spearman's rho) of the C-1 seam

\begin{tabular}{|l|c|c|c|c|c|c|}
\hline \multicolumn{1}{|c|}{ Description } & $\begin{array}{c}\text { Seam } \\
\text { thickness } \\
(\mathbf{S T})\left({ }^{*}\right)[\mathbf{m}]\end{array}$ & $\begin{array}{c}\text { Calorific value } \\
(\mathbf{L H V})(\mathbf{Q r}) \\
{[\mathbf{G J} / \mathbf{M g}]}\end{array}$ & $\begin{array}{c}\text { Sulphur } \\
\text { content (Sr) } \\
{[\mathbf{\%}]}\end{array}$ & $\begin{array}{c}\text { Ash content } \\
(\mathbf{A r})[\%]\end{array}$ & $\begin{array}{c}\text { Coal density } \\
(\mathbf{C d})\left[\mathbf{g} / \mathbf{c m}^{\mathbf{3}}\right]\end{array}$ & $\begin{array}{c}\text { Coal } \\
\text { partings (P) } \\
{[\mathbf{m}]}\end{array}$ \\
\hline Seam thickness & 1.00 & -0.18 & 0.31 & 0.36 & 0.19 & 0.15 \\
\hline Calorific value $($ LHV) & -0.18 & 1.00 & -0.01 & -0.67 & -0.54 & -0.05 \\
\hline Sulphur content & 0.31 & -0.01 & 1.00 & 0.22 & 0.13 & 0.04 \\
\hline Ash content & 0.36 & -0.67 & 0.22 & 1.00 & 0.78 & 0.03 \\
\hline Coal density & 0.19 & -0.54 & 0.13 & 0.78 & 1.00 & 0.04 \\
\hline Coal partings & 0.15 & -0.05 & 0.04 & 0.03 & 0.04 & 1.00 \\
\hline
\end{tabular}

Description: $\left(^{*}\right)$ - seam thickness without coal partings. Source: own study.

\subsection{The key technical, economic, and financial assumptions}

The discounted cash flow analysis for all simulation models assumed the following values of the decision-making parameters:

- Construction phase and achieving maximum production capacity: 6 years,

- Longwall area (the $\mathrm{C} 1$ seam): $43.88 \mathrm{~km}^{2}$,

- The coal production, depending on the amount of reserves, in the following ranges:

- 5 million Mg per year for recoverable reserves below 120 million Mg,

- 8 million Mg per year for recoverable reserves in the range between $121 \div 160$ million $\mathrm{Mg}$,

- 12 million $\mathrm{Mg}$ per year for recoverable reserves over 160 million $\mathrm{Mg}$,

- The base value of the cash operating costs: 195.0 PLN/Mg,

- The share of fixed and variable costs: $65 \%$ and $35 \%$, respectively,

- The coal price: $240.0 \mathrm{PLN} / \mathrm{Mg}$,

- The discount rate: $3.0 \%$,

- Capital expenditures: 6.95 billion PLN, including:

- Expenditures related to the opening and construction of mining levels: 1.50 billion PLN,

- Replacement investments: 5.45 billion PLN

- Corporate Income Tax: 19\%,

- The average values of the deposit parameters for coal and/or gangue, respectively:

- The coal $L H V: 28.56 \mathrm{GJ} / \mathrm{Mg}$ and $1.5 \mathrm{GJ} / \mathrm{Mg}$,

- The sulphur content,: $1.32 \%$ and $1.0 \%$,

- The ash content: $9.29 \%$ and $30.0 \%$,

- The density of coal: $1.34 \mathrm{~g} / \mathrm{cm}^{3}$ or $2.4 \mathrm{~g} / \mathrm{cm}^{3}$,

- The thickness of the C-1 deposit (without coal partings): $2.06 \mathrm{~m}$,

- The coal partings thickness: $0.14 \mathrm{~m}$.

On the basis of the adopted assumptions, the mining height was estimated to be $2.60 \mathrm{~m}$, while the average lifetime to be 24 years using a deterministic approach. The amount of the reserves (as the product of surface, the density and thickness) in the seam was estimated, using a deterministic approach, to be 121.2 million $\mathrm{Mg}$. The average yield of coal was estimated to be $70.1 \%$. The discount rate was assumed at 3.0\%, which corresponded to the risk-free rate (specific risk is expressed by the variability of individual variables in the statement of cash flows). This corresponds to the level of systematic risk and expresses the research objectives of the paper. 


\section{Research results and conclusions}

At first, the $\left\{N P V_{\text {det }}-N P V_{\left(c^{+}\right)}\right\}$and $\left\{I R R_{\text {det }}-I R R_{\left(c^{+}\right)}\right\}$distribution of differences were presented (Fig. 4 and 5).

Analyzing the first distribution (Fig. 4) it can be stated that it is relatively symmetric and similar in shape to the normal distribution (skewness close to 0 ; kurtosis at 2.85), while $90 \%$ of observations is in the range between -1.77 billion to 1.53 billion PLN. The average value of differences between the NPV stood at -119.7 million PLN. In the case of the distribution of differences between IRR (Fig. 5) can be stated that it is characterized by a weak left-sided asymmetry and kurtosis at 2.74 . The $5 \%$ and $95 \%$ percentile determine the $90 \%$ confidence interval $(-18.8 \div 11.0) \%$ with the mean value of $-2.4 \%$. Therefore, the following conclusion can be drawn:

- When using a deterministic approach, the $N P V$ estimation error (excluding the volatility and correlation) reaches the level of 119.7 million in relative terms, while related to the average $N P V$ value it amounts to $11.8 \%$. However, given various combinations of descriptive parameters, the $N P V$ variation in the range $-3.84 \div 2.75$ billion PLN can be expected. Such a large variation results from the medium and low correlation of deposit parameters in this seam.

- The $I R R$ estimation error measured by the average value amounts to $-2.4 \%$ (this value shows the level of overestimation of IRR in relation to the deterministic model), but may vary in the range between $31.3 \%$ and $17.6 \%$.

The effect of correlation resulting from the comparison of the differential values of $N P V$ and $I R R$ is presented in Figures 6 and 7. In the case of differences $\left\{N P V_{i\left(C^{-}\right)}-N P V_{i\left(C^{+}\right)}\right\}$a regular, symmetrical histogram, similar to the the normal distribution, was obtained. The observed distri-

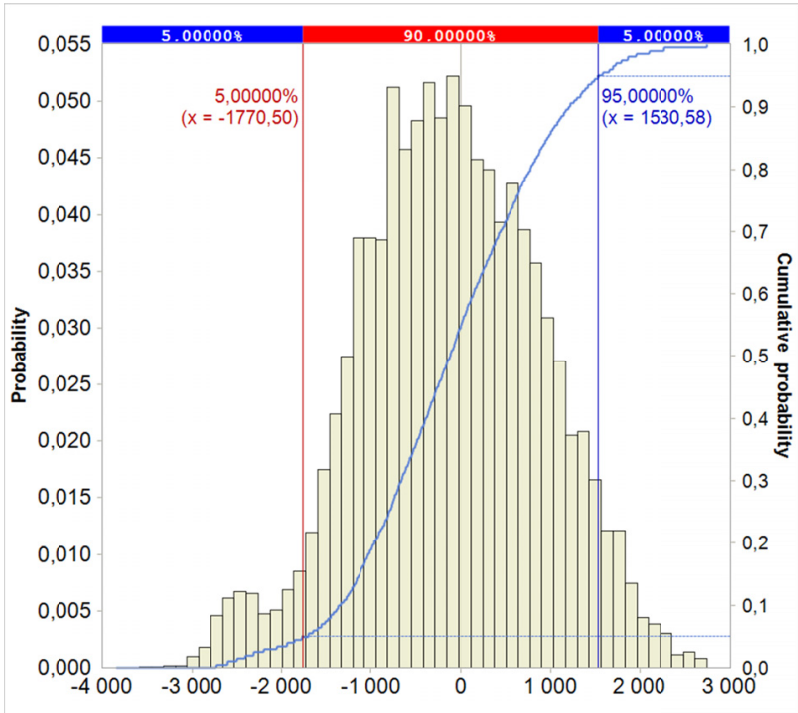

\begin{tabular}{|c|c|}
\hline Description & $\begin{array}{c}\text { Distribution } \\
\text { statistics }\end{array}$ \\
\hline \multicolumn{2}{|c|}{ Location [million PLN] } \\
\hline Mean & -119.7 \\
\hline Minimum & -3846.7 \\
\hline Maximum & 2752.9 \\
\hline \multicolumn{2}{|l|}{ Spread } \\
\hline Standard deviation & 1009.5 \\
\hline Variability & $10192 \mathrm{E}+9$ \\
\hline Coefficient of variation & -8.44 \\
\hline \multicolumn{2}{|l|}{$\begin{array}{r}\text { Shape } \\
\end{array}$} \\
\hline Skewness & -0.09 \\
\hline Kurtosis & 2.85 \\
\hline \multicolumn{2}{|c|}{ Percentiles [million PLN] } \\
\hline $5 \%$ & -1770.5 \\
\hline $95 \%$ & 1530.6 \\
\hline
\end{tabular}

Fig. 4. Distributions of differences of the $\left\{N P V_{d e t}-N P V_{\left(c^{+}\right)}\right\}$. Source: own study 


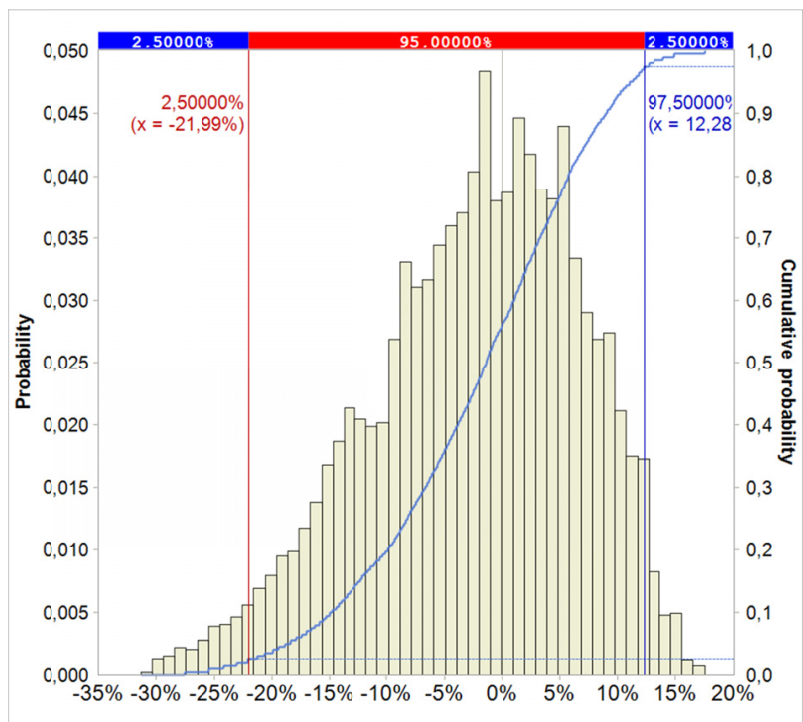

\begin{tabular}{|c|c|}
\hline Description & $\begin{array}{l}\text { Distribution } \\
\text { statistics }\end{array}$ \\
\hline \multicolumn{2}{|c|}{ Location } \\
\hline Mean & $-2.4 \%$ \\
\hline Minimum & $-31.3 \%$ \\
\hline Maximum & $17.6 \%$ \\
\hline \multicolumn{2}{|l|}{ Spread } \\
\hline Standard deviation & 0.09 \\
\hline Variability & 0.01 \\
\hline Coefficient of variation & -3.80 \\
\hline \multicolumn{2}{|l|}{ Shape } \\
\hline Skewness & -0.45 \\
\hline Kurtosis & 2.74 \\
\hline \multicolumn{2}{|c|}{ Percentiles } \\
\hline $5 \%$ & $-18.8 \%$ \\
\hline $95 \%$ & $11.0 \%$ \\
\hline
\end{tabular}

Fig. 5. Distributions of differences of the $\left\{I R R_{\text {det }}-I R R_{\left(c^{+}\right)}\right\}$. Source: own study

bution fluctuates in the range between -5.79 billion and 6.00 billion PLN. Similarly, the obtained distribution of differences $\left\{I R R_{i\left(C^{-}\right)}-I R R_{i\left(C^{+}\right)}\right\}$is characterized by symmetry and parameters similar to normal distribution, while the average value in the discussed distribution was $-0.4 \%$ with the minimum and maximum values in the range of $-48.2 \%$ and $44.7 \%$, respectively. On this basis, the following conclusions can be drawn:

- The numerical value of the error resulting from not taking into account the correlation measured using the average difference in NPV amounts to 33.8 million PLN, which in relative terms is $3.3 \%$,

- Not taking into account the correlation results in overestimation of the deterministic IRR by an average of $0.4 \%$,

- The distributions of differences used to measure the correlation effects, however, have greater spread than those measuring the correlated variability of $N P V$ and $I R R$.

- Correlations of deposit parameters:

- Significantly limit the range of variation estimated for $N P V$ and $I R R$. As a consequence, observations that are unlikely to occur are disqualified,

- Affect the shape and position statistics; hence the average values of the differential effects are different from 0 .

The ranking of deposit parameters influencing the $N P V$ and $I R R$ is presented in Figure 8. The impact of individual deposit variables is determined using Tornado charts, also representing the sensitivity analysis of the simulation model. In the case of the $N P V$, the parameters are ranked based on the strength of the rank correlation, while for the $I R R$ they are related to the conditional mean value. In the case of the rank correlation, the strength and direction of the impact on the $N P V$ are determined (deviation to the right indicates the compatible direction, i.e. the increase of a given parameter increases the $N P V$ and vice versa). 


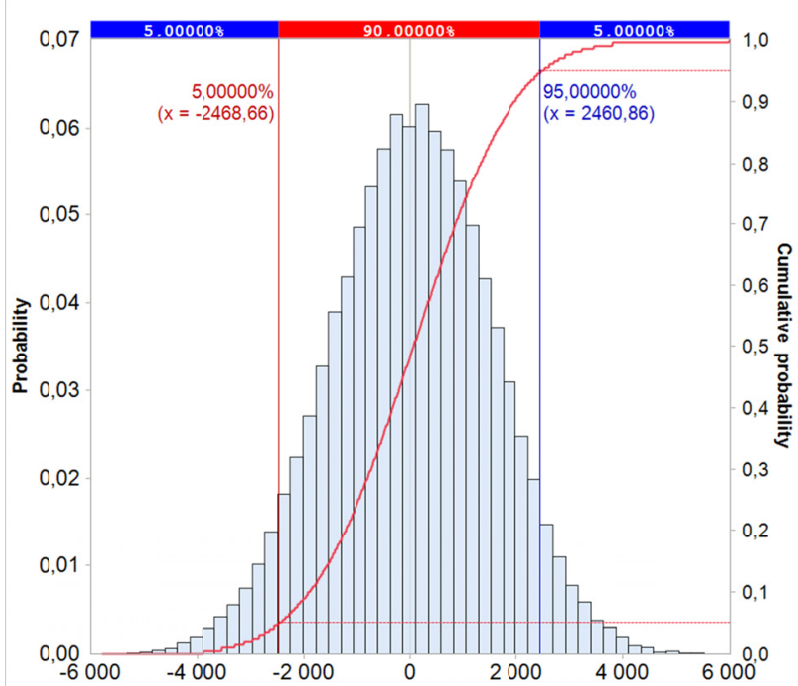

\begin{tabular}{|c|c|}
\hline Description & $\begin{array}{l}\text { Distribution } \\
\text { statistics }\end{array}$ \\
\hline \multicolumn{2}{|c|}{ Location [million PLN] } \\
\hline Mean & 33.8 \\
\hline Minimum & -5788.9 \\
\hline Maximum & 5995.9 \\
\hline \multicolumn{2}{|l|}{ Spread } \\
\hline Standard deviation & 1503.1 \\
\hline Variability & $225919 \mathrm{E}+9$ \\
\hline Coefficient of variation & 44.44 \\
\hline \multicolumn{2}{|l|}{ Shape } \\
\hline Skewness & -0.06 \\
\hline Kurtosis & 2.93 \\
\hline \multicolumn{2}{|c|}{ Percentiles [million PLN] } \\
\hline $5 \%$ & -2468.7 \\
\hline $95 \%$ & 2460.9 \\
\hline
\end{tabular}

Fig. 6. The distribution of the $N P V$ „correlation effect” and its basic descriptive statistics. Source: own study

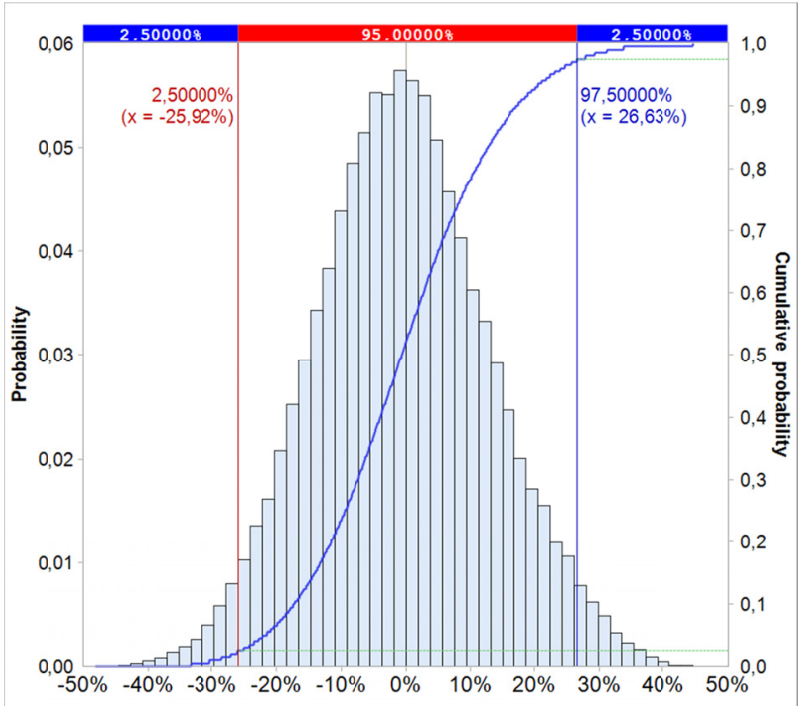

\begin{tabular}{|c|c|}
\hline Description & $\begin{array}{c}\text { Distribution } \\
\text { statistics }\end{array}$ \\
\hline \multicolumn{2}{|l|}{ Location } \\
\hline Mean & $-0.4 \%$ \\
\hline Minimum & $-48.2 \%$ \\
\hline Maximum & $44.7 \%$ \\
\hline \multicolumn{2}{|l|}{ Spread } \\
\hline Standard deviation & 0.13 \\
\hline Variability & 0.02 \\
\hline Coefficient of variation & -30.75 \\
\hline \multicolumn{2}{|l|}{ Shape } \\
\hline Skewness & 0.09 \\
\hline Kurtosis & 2.88 \\
\hline \multicolumn{2}{|l|}{ Percentiles } \\
\hline $5 \%$ & $-22.0 \%$ \\
\hline $95 \%$ & $22.4 \%$ \\
\hline
\end{tabular}

Fig. 7. Distribution of the ,correlation effect” based on IRR and its basic statistics. Source: own study

It can be seen that the seam thickness and the coal $L H V$ have the greatest impact on the $N P V$ and IRR. Meanwhile, the variability in the distribution of ash content (which is strongly correlated with the coal $L H V$ ) and the density of coal have the lowest impact on the $N P V$. The partings thickness and density of coal (the least variable parameter) has the lowest impact on the IRR. Generally it can be stated that in the case of a conditional mean value and the $I R R$, the 

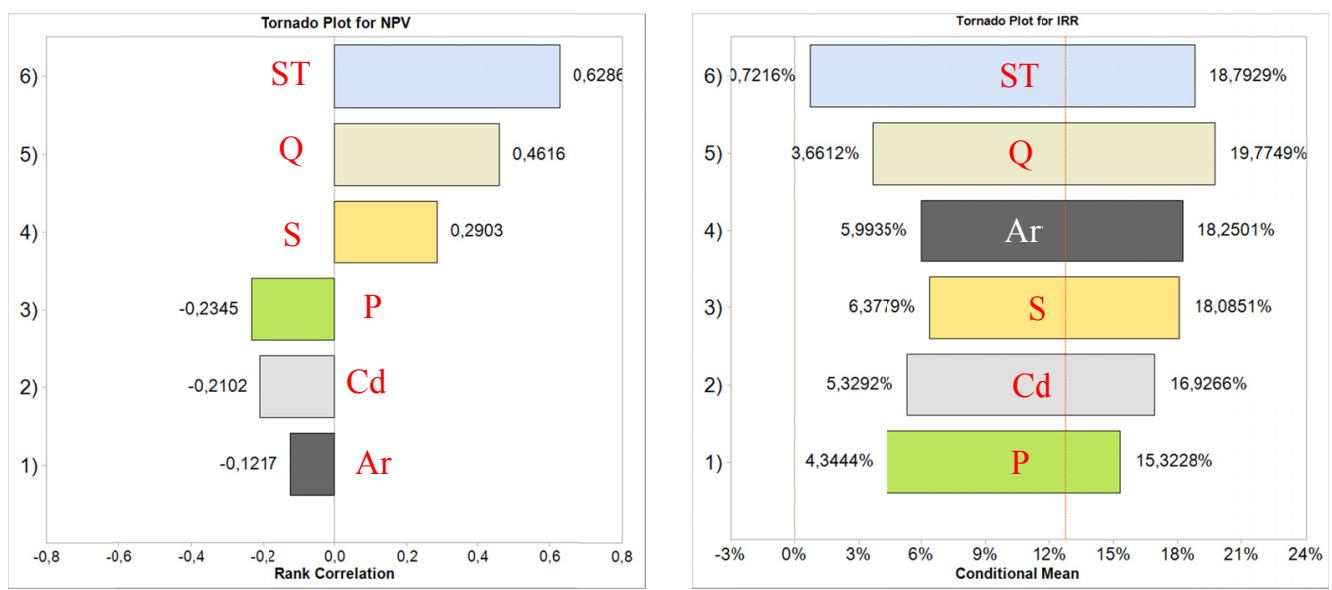

Fig. 8. The sensitivity analysis: Tornado charts of the NPV (rank correlation) and IRR (conditional mean). Source: own study

impact of individual variables is much less variable and characterized by an increased exposure on the left side of the chart (negative influence on the average value of the IRR).

The equal impact of the sulphur content of both the $N P V$ and $I R R$ may seem surprising. However, this is not due to the sulfur content alone, but due to the seam thickness (without coal partings), although the pricing formula recognizes the negative impact of sulphur.

\section{Summary and conclusions}

In order to verify the obtained differential results, the same examination procedure was performed for two other seams of the " $X$ " deposit. The key parameters describing the individual seams and the results of the analysis are summarized in Table 4.

The influence of geological parameters on the NPV and IRR indicators for different coal seams of the " $X$ " deposit

\begin{tabular}{|c|c|c|c|c|}
\hline \hline Description & U.M. & Seam C-1 & Seam C-2 & Seam C-3 \\
\hline $\mathbf{1}$ & $\mathbf{2}$ & $\mathbf{3}$ & $\mathbf{4}$ & $\mathbf{5}$ \\
\hline Reserves & {$[$ million Mg] } & 121.2 & 84.5 & 54.1 \\
\hline Lifetime & {$[$ years] } & 24 & 23 & 18 \\
\hline Capex & {$[$ billion PLN] } & 6.95 & 5.03 & 3.18 \\
\hline Calorific value $(\mathrm{LHV})$ & {$[\mathrm{GJ} / \mathrm{Mg}]$} & 28.56 & 25.2 & 27.15 \\
\hline Sulphur content & {$[\%]$} & 1.32 & 0.97 & 1.43 \\
\hline Ash content & {$[\%]$} & 9.29 & 17.39 & 12.15 \\
\hline Seam thickness $(*)$ & {$[\mathrm{m}]$} & 2.06 & 1.46 & 1.8 \\
\hline Coal density & {$\left[\mathrm{g} / \mathrm{cm}^{3}\right]$} & 1.34 & 1.41 & 1.38 \\
\hline Partings thickness & {$[\mathrm{m}]$} & 0.14 & 0.17 & 0.24 \\
\hline
\end{tabular}




\begin{tabular}{|c|c|c|c|c|}
\hline $\mathbf{1}$ & $\mathbf{2}$ & $\mathbf{3}$ & $\mathbf{4}$ & $\mathbf{5}$ \\
\hline \multirow{2}{*}{$N P V_{d e t}-N P V_{\left(c^{+}\right)}$} & {$[$million PLN] } & -119.7 & -55.1 & -36.1 \\
\cline { 2 - 5 } & {$[\%]$} & $-11.8 \%$ & $-8.1 \%$ & -7.0 \\
\hline$\left\{I R R_{d e t}-I R R_{\left(c^{+}\right)}\right\}$ & {$[\%]$} & $-2.40 \%$ & $-0.80 \%$ & $-1.80 \%$ \\
\hline \multirow{2}{*}{$N P V_{i\left(C^{-}\right)}-N P V_{i\left(C^{+}\right)}$} & {$[$million PLN] } & 33.8 & 29.9 & 9.3 \\
\cline { 2 - 5 } & {$[\%]$} & $3.3 \%$ & $4.4 \%$ & $1.8 \%$ \\
\hline$\left\{I R R_{i\left(C^{-}\right)}-I R R_{i\left(C^{+}\right)}\right\}$ & {$[\%]$} & $-0.40 \%$ & $0.10 \%$ & $-0.20 \%$ \\
\hline The most influencing parameters & - & ST, Q, S, Ar & $\mathrm{Q}, \mathrm{Cd}, \mathrm{Ar}, \mathrm{P}$ & $\mathrm{Q}, \mathrm{Ar}, \mathrm{Cd}, \mathrm{P}$ \\
\hline
\end{tabular}

To sum up, on the basis of the average differences in $N P V$ and $I R R$ it can be stated that:

- The additional risk premium resulting from the volatility of parameters of bituminous coal deposits should be relatively low. In the case of the $I R R$, the percentage value for the analyzed seams of the " $\mathrm{X}$ " deposit does not exceed $2.4 \%$. In the case of the $N P V$, the maximum (relative, referenced to the deterministic $N P V$ ) calculation error reaches the level of $11.8 \%$ Deterministic models overestimated the value of both these measures every time for all analyzed seams.

- The effect of the coexistence of geological variables measured by the level of correlation does not exceed $4.5 \%$ of the total $N P V$ calculated using a deterministic model, while in the case of the $I R R$ this value amounts to $0.4 \%$,

- The distribution of parameters with the highest influence on the $N P V$ and $I R R$ is highly variable. However, the impact of the seam thickness, the coal $L H V$, and the intergrowth thickness is dominating,

- The impact of the analyzed geological parameters on the NPV and $I R R$ depends primarily on the strength and relationship between deposit parameters and their co-existence, which can be measured by the strength of correlation. The stronger the effect of the correlation, the greater the expected differences in the deformation of the projected distributions,

- The importance of the amount of the available information and the variability of individual deposit parameters, if their impact does not negatively affect the regularity and symmetry of distributions, is of secondary importance in the valuation of bituminous coal deposits on the basis of average values.

With suitably large data sample, the value of the volatility of deposit parameters premium should not be too large, given the distribution of the impact of correlation remains symmetrical. The assessment in these circumstances - on the basis of the mean values - using deterministic and probabilistic approach at the same level of discount will allow achieving similar estimates using a discounted cash flow analysis.

\section{References}

Berry M., McCarthy P.L., 2006. Practical consequences of geological uncertainty. [In:] Proceedings 6th International Mining Geology Conference, Melbourne: The Australasian Institute of Mining and Metallurgy, 253-258.

Cherubini U., Luciano E., Vecchiato W., 2004. Copula Methods in Finance. John Wiley \& Sons Ltd, Oxford, UK.

Davis G.A., 1998. One project, two discount rates. Mining Engineering 50 (4), 70-74. 
Dimitrakopoulos R., Scott J., Dunn D., 2007. Quantification of Geological Uncertainty and Risk Using Stochastic Simulation and Applications in the Coal Mining Industry. [In:] Orebody Modelling and Strategic Mine Planning Uncertainty and Risk Management International Symposium 2004, 22-24 November 2004, 185-192.

Efron B., Tibshirani R.J., 1993. An introduction to the Bootstrap. Chapman \& Hall, New York.

Gocht W.R., Zantop H., Eggert R.G., 1988. International Mineral Economics. Springer-Verlag.

Górecka M., 1981. Analiza dokładności rozpoznania złóż węgla kamiennego w wybranym rejonie GZW. Przegląd Geologiczny 29, 4, Warszawa, 162-165.

Graham J., Harvey C., 2001. The theory and practice of corporate finance: evidence from the field. Journal of Financial Economics 60, 187-24.

Grudziński Z., 2009. Propozycje struktur cenowych dla węgla kamiennego energetycznego i węgla brunatnego. Polityka Energetyczna 12 (2/2), Kraków, 159-171.

Hammond D.R., 2000. Current issues in the valuation of international mining assets. Presentation to the International Mining Professionals Society, Hammond International Group, Denver, Colorado, December 13.

Khanzode V.V., Maiti J., Ray P.K., 2001. A methodology for evaluation and monitoring of recurring hazards in underground coal mining. Safety Science 49, 8-9, 1172-1179.

Kopacz M., 2015a. Ocena kosztów gospodarki skała płonną w funkcji zmiennego poziomu współczynnika uzysku węgla netto na przykładzie kopalni węgla kamiennego, Gospodarka Surowcami Mineralnymi 31, 3, Kraków, 121-144.

Kopacz M., 2015b. The impact assessment of quality parameters of coal and waste rock on the value of mining investment projects - hard coal deposits. Mineral Resources Management 31, 4, Krakow, 161-188.

Kopacz M., 2016. Ocena wplywu miąższości, gęstości przestrzennej oraz przerostów w pokładzie węgla na wartość górniczych projektów inwestycyjnych w metodzie symulacyjnej. Przegląd Górniczy 5, Katowice, 63-78.

Kozubski F., 1962. Zagadnienie dokładności rozpoznania tektoniki złóż za pomoca wierceń w świetle potrzeb projektowania górniczego, Przegląd Geologiczny 12, 629-632.

Lattanzi Ch.R., 2000. Discounted cash flow analysis-input parameters and sensitivity. Special session on valuation of mineral properties - Mining Millennium 2000, Toronto, access online on 15.03.2017: http://web.cim.org/mes/pdf/ valdaychrislattanzi.pdf

Le Bel G., 1994. Determination of the Optimum Lifetime of a Mining Project Using Discounted Cash Flow and Option Pricing Techniques by B. Cavender-Discussion. Mining Engineering, 1994, access online on 15.03.2017: http://www. onemine.org/document/abstract.cfm?docid $=6845 \&$ title=Discussion--Determination-Of-The-Optimum-Lifetime-OfA-Mining-Project-Using-Discounted-Cash-Flow-And-Option-Pricing-Techniques--Cavender-B

Li S., Knights P., Dunn D.J., 2008. Geological uncertainty and risk: implications for the viability of mining projects. Journal of Coal Science and Engineering (China) 14, 2, 176-180.

Mucha J., Nieć M., Saługa P., Sobczyk E.J., Wasilewska M., 2008. Ryzyko inwestycji w górnictwie węgla kamiennego jako funkcja dokładności oszacowań parametrów złożowych. Gospodarka Surowcami Mineralnymi 24, 2, Kraków, $161-173$.

Mucha J., Nieć M., Wasilewska M., Sobczyk E.J., Saługa P., 2007. Dokładność szacowania zasobów węgla kamiennego jako element oceny ryzyka inwestycyjnego. Wyd. AGH, Kraków.

Nieć M., 1990. Geologia kopalniana. Wydawnictwa Geologiczne, Warszawa.

Pera K., 2010. Zintegrowana ocena efektywności finansowej surowcowego projektu inwestycyjnego. wyd. Akademii Ekonomicznej, Katowice.

Roberts C., 2000. The Valuation of Advanced Mining Projects and Operating Mines: Market Comparable Approaches. Mineral Economics Society, Special Session on Valuation of Mineral Properties Mining Millennium 2000, Toronto, Ontario, access online on 15.03.2017: www.infomine.com/library/publications/docs/roberts2006.pdf

Saługa P., 2009. Ocena ekonomiczna projektów i analiza ryzyka w górnictwie. Studia, Rozprawy, Monografie, nr 152, IGSMiE PAN, Kraków.

Simonsen H., Perry J., 1999. Risk identification, assessment and management in the mining and metallurgical industries. Journal of the South African Institute of Mining and Metallurgy, 321-332. access online on 15.03.2017: https://www. saimm.co.za/Journal/v099n06p321.pdf

Smith L.D., 1994. Discount rates and risk assessment in mineral project evaluations. Transactions, Mining industry section; Institution of mining and metallurgy, access online on 15.03.2017: https://www.researchgate.net/publication/279553916_Discount_rates_and_risk_assessment_in_mineral_project_evaluations 


\section{4}

Smith L.D., 2000. Discounted cash flow analysis and discount rates. Special session on valuation of mineral properties mining millennium 2000, Toronto, Ontario, access online on 15.03.2017: http://web.cim.org/mes/pdf/valdaylarrysmith.pdf

Sobczyk E.J., 2009. Uciążliwość geologiczno-górniczych warunków eksploatacji węgla kamiennego i jej wplyw na gospodarkę złożem. Studia, Rozprawy i Monografie, nr 150, wyd. IGSMiE PAN, Kraków.

Uberman R., Uberman R., 2008. Podstawy wyceny wartości złóż kopalin. Teoria i praktyka, wyd. IGSMiE PAN, Kraków. Vose D., 2008. Risk analysis. A quantitative guide. John Wiley\&Sons Ltd.: 3rd edition, Chichester, West Sussex, England.

Wasilewska M., Mucha J., 2006. Dokładność szacowania średnich wartości parametrów pokładów węgla kamiennego w blokach obliczeniowych metodą krygingu zwyczajnego. Przegląd Górniczy 62, 11, 10-17.

Zhu B., 2011. Quantitative evaluation of coal-mining geological condition. Procedia Engineering 26, 630-639. 